\title{
Öğretmenlerin Özel Gereksinimli Bireylere Yönelik Tutumlarının İncelenmesi
}

\author{
Ata Pesen ${ }^{\mathrm{a}}$, Merve Demirhan ${ }^{\mathrm{b}}$
}

\section{Özet}

$\mathrm{Bu}$ araştırmanın amacı, öğretmenlerin özel gereksinimli bireylere yönelik tutumlarını çeşitli değişkenler açısından incelemektir. Çalışmanın örneklemini 2017-2018 eğitim-öğretim yılının güz döneminde Siirt il merkezinde görev yapan 468 ilkokul ve ortaokul öğretmeni oluşturmaktadır. Araştırma tarama modeli türlerinden genel tarama modelinde yürütülmüştür. Araştırmada veri toplama aracı olarak Yaralı (2015) tarafından geliştirilen "Özel Gereksinimli Bireylere Yönelik Tutum Ölçeği" kullanılmıştır. Verilerin analizi SPSS 25.0 istatistik paket programı ile yapılmıştır. Veriler normal dağımı sağlamadığından Mann Whitney $U$ testi ve Kruskall Wallis testi uygulanmıştır. Araştırma sonucunda ailede ya da çevrede özel gereksinimli birey bulunma, kıdem ve branş değişkenlerine göre öğretmenlerin özel gereksinimli bireylere yönelik tutumlarında anlamlı farklılıklar tespit edilmiştir. Buna karşın cinsiyet ve çalışılan öğretim kademe değişkenlerinde öğretmenlerin özel gereksinimli bireylere yönelik tutumlarında anlamlı bir farklılık tespit edilmemiştir.
Anahtar Kelimeler

Özel gereksinim

Öğretmen

Öğrenci

Tutum

Makale Hakkında

Geliş Tarihi: 29.10.2019

Kabul Tarihi: 26.03.2021

Doi: $10.18026 /$ cbayarsos.652806

\section{Investigation of Teachers' Attitudes towards Individuals with Special Needs}

\begin{abstract}
This paper aims to investigate the attitudes of teachers towards individuals with special needs in terms of different variables. The sample of the study consisted of 468 primary and secondary school teachers working in the city center of Siirt during the fall semester of the 2017-2018 academic year. The study was carried out applying the general survey model, one of the survey models. "An Attitude Scale Towards Individuals with Special Needs" developed by Yarali (2015) was used as the data collection tool for the study. The Mann Whitney U test and the Kruskal Wallis test were used to compare the averages in the study. As a result of the research, significant differences were found in the attitudes of the teachers towards the special needs individuals according to the variables of the presence of individuals with special needs in the family or environment, seniority and branch of the teachers. However, no significant difference was found in the attitudes of teachers towards individuals with special needs in terms of gender and teaching grade variables.
\end{abstract}

Keywords

Individual with Special Needs

Teacher

Student

Attitude

About Article

Received: 29.10.2019

Accepted: 26.03.2021

Doi: 10.18026/cbayarsos.652806

a Dr. Öğr. Üyesi, Siirt Üniversitesi, Eğitim Fakültesi, Eğitim Programları ve Öğretim Bölümü, atapesen@siirt.edu.tr, ORCID: 0000-0003-1676-7444

b Özel Eğitim Öğretmeni, Siirt Türk Telekom Özel Eğitim ilkokulu, mervedemrhn@gmail.com, ORCID: 0000-0003-3311-7160 


\section{Giriş}

Günümüzde eğitimde fırsat eşitliği ilkesiyle özel eğitime ihtiyaç duyan bireyler eğitim ortamlarında daha fazla yer almaktadırlar. Sınıflarda özel eğitime ihtiyaç duyan bireylerin varlığ1 ile öğretmenler sınıf ortamında yeniliklere ve değişikliklere yer vermektedirler. Öğretmenler, sınıflarında özel gereksinimli bireyin bulunacağını öğrendiği andan itibaren olumlu ya da olumsuz tutum sürecine girebilmektedirler. "Beden, zihin, duygu ve sosyal özelliklerindeki olağan dışı ayrıcalıkları nedeni ile normal eğitim hizmetlerinden yeterince yararlanamayan çocuklar" (Enç, Çağlar ve Özsoy, 1987) şeklinde tanımlanan özel gereksinimli çocukların eğitimi; öğretmenin özel eğitimle ilgili gerekli beceri ve bilgilere sahip olmasının (Ferguson \& Ralph, 1996; Garner, 1996) yanında duyarlılık, anlayış, sabır ve bilgi gerektiren bir iştir. Özel gereksinimli bireylerle kaynaştırma eğitimi aracılığı ile muhatap olan eğitimcilerin özel gereksinimli bireylere yönelik tutumu özel eğitime olan tutumlarının da temel belirleyicisidir. Eğitimcinin, özel gereksinimli çocuklara ilişkin olumlu tutum içinde olması özel gereksinimi olan çocuklar kadar normal gelişim gösteren çocuklar açısından da büyük önem taşımaktadır (Temel, 2000). Vaz ve arkadaşlarına (2016) göre öğretmenlerin özel eğitime yönelik tutumları belirli bir ideolojiye dayanmak yerine özel eğitimin nasıl uygulanabileceğine dair pratik kaygılara dayanmaktadır.

Özel gereksinimli bireylerin fırsat eşitliğinden yararlanmaları için en az kısıtlayıcı ortamın vurgulandığı bir dönemde, akademik ve sosyal becerilerinin gelişmesinde öğretmen tutumları ön plana çıkmaktadır (Sarı ve Saygın, 2001). Özel gereksinimli bireyler akranlarından ayrıştırılmadan normal gelişim gösteren öğrencilerle beraber en az sınırlandırılmış ortam diye adlandırdığımız kaynaştırma programında yer almaktadırlar. Özel gereksinimli bireyler kendilerine sunulan ek hizmetler ile normal gelişim gösteren öğrencilerle beraber eğitim görmektedirler (Eripek, 2007). Özel eğitimin şu an ve ilerleyen senelerdeki başarısında yer alan en önemli etmenlerden birisi öğretmen tutumlarıdır. Özel eğitimdeki başarının öğretmen tutumlarıyla ilişkili olduğu tezi bugün hala geçerliliğini korumaktadır (Atay, 1995) Özel gereksinimli bireylerin sosyalleşmelerinde ve eğitim süreçlerinde büyük rol öğretmenlere düşmektedir (Rizzo, 1985). Shapiro'ya (1999) göre tutumlar sınıfta yapılan etkinlikler boyunca öğretmenlerin davranışlarını ve öğretmenlerin öğrencilerinden beklentilerini etkilemektedir. Yani öğretmenlerin davranışları, beklentileri ve tutumları öğrencilerin hem bilişsel hem de sosyal becerilerine etkide bulunmaktadır (Alexandre ve Strain, 1978).

Cüceloğlu (1996) tutumları organize edilmiş uzun süreli duygu, inanç ve davranış eğilimi şeklinde tanımlamaktadır. Bizer, Barden ve Petty (2003) tutumları, bilişsel, duyuşsal ve davranışsal bileşenleri içeren göreceli olarak kararlı yapılar olarak kavramsallaştırırken Petty ve Cacioppo (1996) tutumların belirleyicisi olarak inanç ve davranışları belirtir (Akt: Kösterlioğlu, 2013). İnceoğlu (2010) ve Tavşancıl, (2014) ise tutumların, bireyin herhangi bir olay, olgu, kişi ya da nesneye ilişkin olduğunu belirtmektedir. Tutumlar aynı zamanda, düşünce, duygu ve davranışlarını biçimlendiren eğilim olarak tanımlanabilir (Ardıç, 2012). Tutumlar bireylerin doğuştan getirmediği, öğrenme yoluyla sonradan kazandıkları inanç, duygu, düşünce ve davranışlardır. Özel gereksinimli bireylere ilişkin tutumlardan kasıt ise bu tür bireylerin engellerinden dolayı insanlarda oluşan inanç, duygu, düşünce ve davranışlardır (Özyürek, 2013). Bandura'ya göre (1986) bireyin davranışları, inançları ve tutumları ile arasında bir bağ bulunmaktadır. Tutum bireylerin gözlemlenebilen ya da gözlemlenemeyen davranışlarının temelinde bulunmaktadır. Alanyazında öğretmenlerin tutumları ile ilgili yapılan çalışmalar öğrenciler üzerinde öğretmenlerin davranış ve tutumlarının önem 
taşıdığını göstermektedir. (Atıcı, 2014; Aydın ve Tekneci, 2013; Çapa ve Çil, 2000; Genç, 2016a; Genç 2016b; Yiğiter, 2005; Çelik, 2011; Temizkan, 2008). Diğer taraftan tutumlar tecrübelerle beraber yön de değiştirebilir (Akyıldız, 2017). Tutumların değişmesi ile ilgili yapılan çalışmalar, etkileşim ve bilgilendirmenin tutumların değişmesinde önemli etkenler olduğu düşüncesi ortaya çıkmıştır (Özyürek, 2006).

Alan yazın incelendiğinde daha çok öğretmenlerin kaynaştırma eğitimine ile ilgili tutumlarının ve görüşlerinin incelenmesine, kaynaştırma eğitiminde karşılaştıkları sorunlara yer verilmiştir (Siegel, 1992; Avramidis, Bayliss ve Burden, 2000; Brownlee ve Carrington, 2000; Orel, Zerey ve Töret, 2004; Akman ve Okyay, 2004; Demirezen ve Akhan, 2016; Ellins ve Porter, 2005; Batu, Kırcaali-İftar, Uzuner, 2004; Özbaba, 2000; Gözün ve Yıkmış, 2004; Yavuz, 2005; Yiğiter, 2005; Çuhadar, 2006; Bilen, 2007; Altun ve Gülben, 2009; Fakolade, Adeniyi \& Tella, 2009; Lynn Cagney, 2009; Sarı, Çeliköz ve Seçer, 2009; Kargın, Güldenoğlu \& Şahin, 2010; Dalğar, 2011; Kuzu, 2011; Sarı ve Bozgeyikli, 2003; Saidoğlu; 2011; Erişkin, Kıraç ve Ertuğrul, 2012; Engin, Tösten, Kaya, Köselioğlu, 2014; Kayhan, Şengül ve Akmeşe, 2012; Daşbaş, Kesen ve Eryılmaz, 2013; Fırat, 2014; Güleryüz, 2014; Vaz ve diğ., 2016). Öğretmen adaylarının (Atalay ve Atalay, 2017; Costello ve Boyle, 2013) ve öğretmenlerin (Çolak ve Çetin, 2014; Daşbaş, Kesen ve Eryılmaz,2013; Demir Atalay ve Atalay, 2017; Parasuram, 2006; S1egel, 1992) özel gereksinimli öğrencilere ilişkin tutumları ile ilgili çalışmalar ise sınırlı sayıdadır

Toplumsal gelişmişlik düzeyi arttıkça farklılıklara saygının artması beklenen bir durum olmasına karşın ne yazık ki Türkiye' de ve dünyanın pek çok ülkesinde farklılıklarından dolayı olumsuz tutumlara maruz kalan birey haberleri sıklıkla karşımıza çıkmaktadır. Farklılıkları ile eğitim sürecine ve topluma dâhil olmaya çalışan özel gereksinimli bireylerin görmeleri gereken en olumlu tutum öğretmenleri tarafından olmalıdır. Bu yüzden öğretmenlerin özel gereksinimli öğrencilere ilişkin tutumlarının incelenmesinin alandaki bir açığ düşünülmektedir.

$\mathrm{Bu}$ araştırma, konu ile ilgili yapılan çalışmalara katkı sağlamak ve özel eğitim öğrencilerine yönelik uygulamalarda öğretmen tutumlarının önemli olduğu düşünülerek gerçekleştirilmiştir.

$\mathrm{Bu}$ araştırmanın amacı, öğretmenlerin özel gereksinimli bireylere yönelik tutumlarını çeşitli değişkenler açısından incelemektir. Bu genel amaç doğrultusunda aşağıdaki araştırma sorularına yanıt aranmıştır:

a. Öğretmenlerin özel gereksinimli bireylere yönelik tutumları cinsiyet, kıdem, görev yapılan öğretim kademesi, branş ve aile içinde veya yakın çevrede özel gereksinimli birey olup olmaması değişkenine göre öğretmenlerin özel gereksinimli bireylere yönelik tutumları arasında istatistiksel olarak anlamlı bir farklılık var mıdır?

\section{Yöntem}

\section{Araştırma Modeli}

Araştırma nicel bir araştırma yöntemlerinden genel tarama modelinde yürütülmüştür. Genel tarama modelleri, birden fazla elemandan oluşan bir evrende, evren hakkında genel bir yargıya varmak sebebiyle, evrenin tümü veya ondan alınacak bir grup, örnek ya da örneklem üzerinde yapılan tarama düzenlemeleridir (Karasar,1995). 


\section{Evren ve Örneklem / Çalışma Grubu / Katılımcılar}

Araştırmanın evrenini 2017-2018 yılı güz eğitim ve öğretim döneminde Siirt il merkezinde görev yapan 2809 ilk ve ortaokul öğretmeni oluşturmaktadır. Örneklem grubu olarak Siirt İli merkezinde yer alan 35 farklı okuldan random yoluyla seçilen 468 ilk ve ortaokul öğretmeni oluşturmaktadır. Tablo 1'de araştırmaya katılan öğretmenlerin demografik özellikleri verilmiştir.

Tablo 1. Katılımcıların Demografik Özelliklerine İlişkin Bilgiler

\begin{tabular}{|c|c|c|c|}
\hline Değişkenler & & $\mathrm{f}$ & $\%$ \\
\hline \multirow{2}{*}{ Cinsiyet } & Kadın & 239 & 51.1 \\
\hline & Erkek & 229 & 48.9 \\
\hline \multirow{2}{*}{ Öğretim Kademesi } & İlkokul & 197 & 42.1 \\
\hline & Ortaokul & 271 & 57.9 \\
\hline \multirow{4}{*}{ Kidem } & $0-5$ & 247 & 52.8 \\
\hline & $6-10$ & 107 & 22.9 \\
\hline & $11-15$ & 69 & 14.7 \\
\hline & 16 yıl ve üzeri & 45 & 9.6 \\
\hline \multirow{11}{*}{ Branş } & Türkçe Öğret. & 39 & 8.3 \\
\hline & Sosyal Bil. Öğret. & 32 & 6.8 \\
\hline & Sınıf Öğretmenliği & 133 & 28.4 \\
\hline & İngilizce Öğret. & 32 & 6.8 \\
\hline & Fen Bilgisi Öğret. & 30 & 6.4 \\
\hline & Din Kült. ve Ahl. Bil. Öğret. & 30 & 6.4 \\
\hline & Matematik Öğret. & 32 & 6.8 \\
\hline & PDR Öğret. & 39 & 8.3 \\
\hline & Okul Öncesi Öğret. & 19 & 4.1 \\
\hline & Özel Eğitim Öğret. & 34 & 7.3 \\
\hline & Diğer & 48 & 10.3 \\
\hline \multirow{2}{*}{ Yakını Olup Olmama } & Evet & 149 & 31.8 \\
\hline & Hayır & 319 & 68.2 \\
\hline
\end{tabular}

Tablo 1 incelendiğinde araştırmaya katılan toplam öğretmen sayısı 468'dir. Bu öğretmenlerden \%51,1'i kadın \%48,9'u erkek öğretmenlerden oluşmaktadır. Öğretmenlerin \%42,1'i ilkokulda \%57,9’u ortaokulda görev yapmaktadır. Öğretmenlerin \%52,8'i 0-5 yıl, $\% 22,9$ 'u 6-10 yıl, \%14,7'si 11-15 yıl, \%9,6'sı ise 16 yıl ve üstü kıdeme sahiptir. Öğretmenlerin \%8,3'ü Türkçe Öğretmeni, \%6,8'i Sosyal Bilgiler Öğretmeni, \%28,4'ü Sınıf Öğretmeni, \%6,8'i 
İngilizce Öğretmeni, \%6,4’ü Fen Bilgisi Öğretmeni, \%6,4’ü Din Kültürü Öğretmeni, \%6,8’i Matematik Öğretmeni, \%8,3'ü Rehber Öğretmen, \%4,1'i Okul Öncesi Öğretmeni, \%7,3'ü Özel Eğitim Öğretmeni, \%10,3’ü ise diğer branşlarda görev yapmaktadır. Çevrelerinde ya da yakınlarında özel gereksinimli birey olanlar öğretmenler \%31,8, olmayanlar ise \%68,2 dilimi oluşturmaktadırlar.

\section{Verilerin Toplanması ve Analizi}

$\mathrm{Bu}$ araştırmada veri toplama aracı olarak Yaralı (2015) tarafından geliştirilen “Özel Gereksinimli Bireylere Yönelik Tutum Ölçeği” kullanılmıştır. Yaralı tarafından yapılan geçerlilik çalışmaları sonucunda, özel gereksinimli bireylere yönelik tutum ölçeğinin 3 faktörde toplam 13 maddeden oluştuğu, faktör yük değerlerinin .551 ile .860 arasında değiştiği, toplam varyansın ise \%58.592'sini açıkladığı belirlenmiştir. Ölçeğin beğeni alt boyutu için Cronbach Alfa iç tutarlılık katsayısı .803, duyarlılık alt boyutu için .812 ve olumsuz tutum alt boyutu için .712 hesaplanırken, ölçeğin bütünün için hesaplanan Cronbach Alfa iç tutarlılık katsayısı .841 olarak belirtilmiştir. Bu araştırma için araştırmacılar tarafından beğeni alt boyutu için Cronbach Alfa iç tutarlılık katsayısı .867, duyarlılık alt boyutu için .867 ve olumsuz tutum alt boyutu için .772 hesaplanırken, ölçeğin bütünün için hesaplanan Cronbach Alfa iç tutarlılık katsayısı .841 olarak hesaplanmıştır. Ölçeğin bütünü için ise Cronbach Alfa iç tutarlılık sayısı .704 olarak hesaplanmıştır. Araştırmada elde edilen veriler SPSS 25.0 veri analiz programı kullanılarak çözümlenmiştir. İstatistiksel analizlerde kullanılacak anlamlılık düzeyi $\mathrm{p} \leq 0,05$ olarak alınmıştır. Araştırmada elde edilen veriler üzerinde yapılan analiz sonucunda verilerin normal dağılım sergilemediğinden Mann Whitney U testi ve Kruskall Wallis H Testi analizleri kullanılmıştır.

\section{Bulgular}

Bu bölümde, bulgular araştırmanın alt problemlerine göre ele alınmış, elde edilen veriler tablo halinde gösterilmiştir. Öğretmenlerin özel gereksinimli bireylere yönelik tutumlarına ilişkin betimsel bulgular tablo 2' de sunulmuştur.

Tablo 2. Öğretmenlerin Özel Gereksinimli Bireylere Yönelik Tutumlarının Faktörlere Yönelik Aritmetik Ortalama ve Standart Sapmaları

\begin{tabular}{|c|c|c|c|}
\hline & Maddeler & $\overline{\boldsymbol{X}}$ & SS \\
\hline & $\begin{array}{l}\text { Özel gereksinimli bireylere toplumda gereken önemin verilmesi için } \\
\text { gerekirse ücret talep etmeden çalışabilirim. }\end{array}$ & 3,76 & 1,09 \\
\hline$\tilde{z}$ & $\begin{array}{l}\text { Özel gereksinimli bireylerle ilgili yapılan yenilikleri takip etmekten } \\
\text { hoşlanıyorum. }\end{array}$ & 3,84 & ,93 \\
\hline صڤ & 3 Özel gereksinimli bireylerle ilgili bir etkinlik yapmak isterim. & 3,92 & ,90 \\
\hline & $\begin{array}{l}\text { Televizyonda özel gereksinimli bireylerle ilgili bir programla karşılaşırsam } \\
\text { onu sonuna kadar izlerim. }\end{array}$ & 3,75 & ,95 \\
\hline & 5 Özel gereksinimli bireyler ile ilgili yayınları takip ediyorum. & 3,31 & 1,01 \\
\hline
\end{tabular}


6

Başkaları ile özel gereksinimli bireyler hakkında sohbet etmekten hoşlanırım.

$3,91 \quad 95$

Toplam

3.75

.75

\begin{tabular}{|c|c|c|c|}
\hline \multirow{5}{*}{ 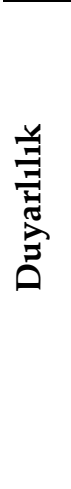 } & Toplumdaki herkese özel gereksinimli bireyler konusunda bilgilendirici & 4.53 & 97 \\
\hline & birtakım etkinliklerin yapılması gerektiğini düşünüyorum. & & \\
\hline & Kitle iletişim araçlarında özel gereksinimli bireylere daha fazla yer & 4,42 & ,97 \\
\hline & $\begin{array}{l}\text { Özel gereksinimli bireylerin eğitimleri hakkında bir şeyler öğrenmek benim } \\
\text { için önemli önemlidir. }\end{array}$ & 4,31 & 1,00 \\
\hline & Toplam & 4.42 & .87 \\
\hline \multirow{5}{*}{ 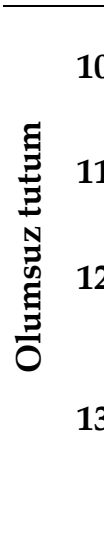 } & $\begin{array}{l}\text { Özel gereksinimli bireye sahip olan ailenin çocuğuna nasıl davrandığıyla } \\
0 \\
\text { iloilenmem. }\end{array}$ & 1,58 & ,93 \\
\hline & 1 Tercih hakkı verilirse sınıfımda özel gereksinimli öğrenci istemem. & 2,21 & 1,19 \\
\hline & $\begin{array}{l}\text { Özel gereksinimli çocuklardan birinin öğretmeni olabileceğimi düşününce } \\
\text { öğretmen olmak istemiyorum. }\end{array}$ & 1,57 & 82 \\
\hline & $\begin{array}{l}\text { Öğretmen olduğumda özel gereksinimli öğrencilerin sınıfımda olması } \\
\text { ihtimali beni korkutur. }\end{array}$ & 1,91 & 1,01 \\
\hline & Toplam & 1.82 & .77 \\
\hline
\end{tabular}

Tablo 2 incelendiğinde, öğretmenlerin özel gereksinimli bireylere yönelik tutumlarında beğeni faktörünün ortalaması 3,75 olarak bulunmuştur. Bu ölçekten alınabilecek en fazla puanın 5.00 olduğu düşünüldüğünde öğretmenlerin özel gereksinimli bireylere yönelik ilgi ve zevk duymalarının yüksek düzeyde olduğu söylenebilir. Öğretmenlerin özel gereksinimli bireylere yönelik tutumlarında Duyarlılık faktör ortalaması 4,42 olarak bulunmuştur. Bu durum öğretmenlerin özel gereksinimli bireylere yönelik duyarlılıklarının çok yüksek düzeyde olduğunu göstermektedir. Öğretmenlerin özel gereksinimli bireylere yönelik olumsuz tutum faktörtörü ortalaması 1,82 olarak bulunmuştur. Buna göre öğretmenlerin özel gereksinimli bireylere yönelik tutumlarının olumlu olduğu söylenebilir.

Öğretmenlerin cinsiyet değişkenine göre özel gereksinimli bireylere yönelik tutumlarına ilişkin bulgular tablo 3 'te sunulmuştur. 
Tablo 3: Öğretmenlerin Cinsiyet Değişkenine Göre Özel Gereksinimli Bireylere Yönelik Tutumlarını Yansitan Bulgular

\begin{tabular}{lllcccc}
\hline Faktörler & Cinsiyet & $\mathbf{N}$ & Sira farkları ort. & $\begin{array}{c}\text { Sira } \\
\text { toplamı }\end{array}$ & U & $\mathbf{p}$ \\
\hline \multirow{2}{*}{ Beğeni } & Kadın & 239 & 240,86 & 57566,50 & 2584.50 & .297 \\
\hline \multirow{2}{*}{ Duyarlılık } & Erkek & 229 & 227,86 & 52179,50 & & \\
& Kadın & 239 & 244,68 & 58478,50 & 2493.50 & .078 \\
\hline \multirow{2}{*}{ Olumsuz tutum } & Erkek & 229 & 223,88 & 51267,50 & & .711 \\
\hline
\end{tabular}

${ }^{*} \mathrm{p}<0,05$

Tablo 3 incelendiğinde, öğretmenlerin cinsiyetlerine göre özel gereksinimli bireylere yönelik tutumlarında istatistiksel olarak anlamlı bir farklılık oluşmadığı görülmüştür.

Öğretmenlerin kıdem değişkenine göre özel gereksinimli bireylere yönelik tutum puanları arasında anlamlı bir farklılık olup olmadığına ilişkin bulgular tablo $4^{\prime}$ te sunulmuştur.

Tablo 4. Öğretmenlerin Kıdem Değişkenine Özel Gereksinimli Bireylere Yönelik Tutumlarını Yansitan Bulgular

\begin{tabular}{|c|c|c|c|c|c|c|c|}
\hline Faktörler & Sinif & $\mathbf{N}$ & Sira ort. & sd & $x^{2}$ & p & Fark \\
\hline \multirow{4}{*}{ Beğeni } & (1)0-5 yıl & 247 & 245.74 & \multirow{4}{*}{3} & \multirow{4}{*}{5.45} & \multirow{4}{*}{.142} & \multirow{4}{*}{ Yok } \\
\hline & (2)6-10 yıl & 107 & 217.51 & & & & \\
\hline & (3)11-15yıl & 69 & 213.23 & & & & \\
\hline & (4)16 yıl ve üstü & 45 & 245.79 & & & & \\
\hline \multirow{4}{*}{ Duyarlılık } & (1)0-5 y1l & 247 & 249.72 & \multirow{4}{*}{3} & \multirow{4}{*}{7.81} & \multirow{4}{*}{$.050^{*}$} & \multirow{4}{*}{$1^{*}-2,4$} \\
\hline & (2)6-10 y1l & 107 & 218.81 & & & & \\
\hline & (3)11-15y1l & 69 & 222.07 & & & & \\
\hline & (4)16 yıl ve üstü & 45 & 207.34 & & & & \\
\hline \multirow{4}{*}{ Olumsuz tutum } & (1)0-5 yıl & 247 & 217.91 & \multirow{4}{*}{3} & \multirow{4}{*}{9.19} & \multirow{4}{*}{$.027^{*}$} & \multirow{4}{*}{$\mathbf{1}^{*}-2,3$} \\
\hline & (2)6-10 y1l & 107 & 248.31 & & & & \\
\hline & (3)11-15yil & 69 & 266.97 & & & & \\
\hline & (4)16 yıl ve üstü & 45 & 242.91 & & & & \\
\hline
\end{tabular}

${ }^{*} \mathrm{p}<0,05$

Tablo 4 incelendiğinde, öğretmenlerin özel gereksinimli bireylere yönelik tutum puanları arasında gözlenen farkın hangi gruplardan kaynaklandığını belirlemek amacıyla Kruskal- 
Wallis H testinden yararlanılmıştır. Öğretmenlerin kıdem değişkenine göre özel gereksinimli bireylere yönelik tutumlarında beğeni faktöründe anlamlı bir farklılık olmamasına karşın duyarlılık ve olumsuz tutum faktörlerinde anlamlı bir farklılık bulunmuştur. Mann-Whitney U testi ile yapılan çoklu karşılaştırmalar sonucunda bu farkın, duyarlılık faktöründe 0-5 yıl, 610 yıl ve 0-5 yıl, 16 yıl ve üstü görev yapan öğretmenler arasında 0-5 yıl kıdemi olan öğretmenlerin lehine anlamlı farklılıklar tespit edilmiştir. Buna göre, kıdemi düşük olan öğretmenlerin özel gereksinimli bireylere yönelik tutumlarında duyarlılık boyutunun daha fazla olduğu tespit edilmiştir. Olumsuz tutum faktöründe $0-5$ yıl, 11-15 yıl ve 0-5 yıl, 11-15 yıl görev yapan öğretmenler arasında 0-5 yıl kıdemi olan öğretmenlerin lehine anlamlı farklılıklar tespit edilmiştir. Buna göre, 0-5 yıl kıdemi olan öğretmenlerin özel gereksinimli bireylere yönelik tutumlarında olumsuz tutum boyutunun diğerlerine oranla daha düşük olduğu tespit edilmiştir.

Öğretmenlerin görev yaptıkları öğretim kademesine göre özel gereksinimli bireylere yönelik tutum puanları arasında anlamlı bir farklılık olup olmadığına ilişkin bulgular tablo 5 'te sunulmuştur.

Tablo 5. Öğretmenlerin Öğretim Kademesi Değişkenine Özel Gereksinimli Bireylere Yönelik Tutumlarını Yansitan Bulgular

\begin{tabular}{lllcccc}
\hline Faktörler & $\begin{array}{l}\text { Öğretim } \\
\text { Kademesi }\end{array}$ & $\mathbf{N}$ & $\begin{array}{c}\text { Sira farkları } \\
\text { ort. }\end{array}$ & $\begin{array}{c}\text { S1ra } \\
\text { toplamı }\end{array}$ & U & p \\
\hline \multirow{2}{*}{ Beğeni } & İlkokul & 197 & 235,89 & 46470,00 & 26420.00 & .849 \\
& Ortaokul & 271 & 233,49 & 63276,00 & & \\
\hline \multirow{2}{*}{ Duyarlılık } & İlkokul & 197 & 234,54 & 46205,00 & 26685.00 & .995 \\
& Ortaokul & 271 & 234,47 & 63541,00 & & \\
\hline \multirow{2}{*}{ Olumsuz tutum } & İlkokul & 197 & 233,34 & 45967,50 & 26464.50 & .873 \\
& Ortaokul & 271 & 235,35 & 63778,50 & & \\
\hline
\end{tabular}

${ }^{*} \mathrm{p}<0,05$

Tablo 5 incelendiğinde, öğretmenlerin özel gereksinimli bireylere yönelik tutum puanları arasında istatistiksel bir anlamlılık olup olmadığını belirlemek amacıyla yapılan MannWhitney U testinde öğretmenlerin bulundukları öğretim kademelerine göre özel gereksinimli bireylere yönelik tutumlarında anlamlı bir farklılık oluşmadığı görülmüştür.

Öğretmenlerin branş değişkenine göre özel gereksinimli bireylere yönelik tutum puanları arasında anlamlı bir farklılık olup olmadığına ilişkin bulgular tablo 6' da sunulmuştur. 
Tablo 6. Öğretmenlerin Branş Değişkenine Göre Özel Gereksinimli Bireylere Yönelik Tutumlarinı Yansitan Bulgular

\begin{tabular}{|c|c|c|c|c|c|c|c|}
\hline & Branş & $\mathbf{N}$ & Sira ort. & sd & $x^{2}$ & $\mathrm{p}$ & Fark \\
\hline \multirow{11}{*}{ 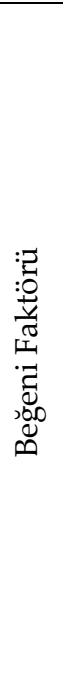 } & (1) Türkçe Öğrt & 39 & 202,54 & \multirow{11}{*}{10} & \multirow{11}{*}{20.23} & \multirow{11}{*}{$.027^{*}$} & \multirow{11}{*}{$\begin{array}{c}1,3,4,6,7,11-8^{*} \\
1,2,3,4,6,7,11-10^{*}\end{array}$} \\
\hline & (2) Sosyal Bilg & 32 & 230,02 & & & & \\
\hline & (3) Sinıf Öğrt & 133 & 232,56 & & & & \\
\hline & (4) İngilizce & 32 & 213,03 & & & & \\
\hline & (5) Fen Bilg & 30 & 247,23 & & & & \\
\hline & (6) Din Kül. Öğrt & 30 & 205,17 & & & & \\
\hline & (7) Matematik Öğrt & 32 & 198,52 & & & & \\
\hline & (8) Rehb. Öğrt & 39 & 285,78 & & & & \\
\hline & (9) Okul Ön. Öğrt & 19 & 267,53 & & & & \\
\hline & (10) Özel Eğt Öğrt & 34 & 291,34 & & & & \\
\hline & (11) Diğer & 48 & 222,50 & & & & \\
\hline \multirow{11}{*}{ 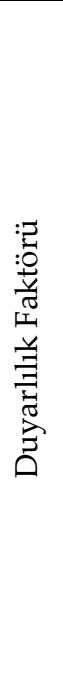 } & (1) Türkçe Öğrt & 39 & 235,06 & \multirow{11}{*}{10} & \multirow{11}{*}{9.06} & \multirow{11}{*}{.526} & \multirow{11}{*}{$2,11-8^{*}$} \\
\hline & (2) Sosyal Bilg & 32 & 205,03 & & & & \\
\hline & (3) Sinif Öğrt & 133 & 234,34 & & & & \\
\hline & (4) İngilizce & 32 & 236,38 & & & & \\
\hline & (5) Fen Bilg & 30 & 246,98 & & & & \\
\hline & (6) Din K Öğrt & 30 & 234,13 & & & & \\
\hline & (7) Matematik Öğrt & 32 & 219,78 & & & & \\
\hline & (8) Rehb Öğrt & 39 & 273,78 & & & & \\
\hline & (9) Okul Ön. Öğrt & 19 & 222,66 & & & & \\
\hline & (10) Özel Eğt Öğrt & 34 & 258,21 & & & & \\
\hline & (11) Diğer & 48 & 211,09 & & & & \\
\hline \multirow{11}{*}{ 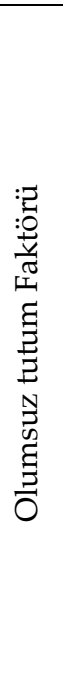 } & (1) Türkçe Öğrt & 39 & 261,47 & & & & \multirow{11}{*}{$\begin{array}{c}1,2,3,4,6,7,11-8^{*} \\
1,2,3,4,5,6,6,7,8,9-10^{*}\end{array}$} \\
\hline & (2) Sosyal Bilg & 32 & 247,63 & & & & \\
\hline & (3) Sinuf Öğrt & 133 & 242,50 & & & & \\
\hline & (4) İngilizce & 32 & 272,11 & & & & \\
\hline & (5) Fen Bilg & 30 & 219,88 & & & & \\
\hline & (6) Din K Öğrt & 30 & 247,18 & 10 & 48.15 & $.000^{* *}$ & \\
\hline & (7) Matematik Öğrt & 32 & 289,36 & & & & \\
\hline & (8) Rehb Öğrt & 39 & 181,99 & & & & \\
\hline & (9) Okul Ön. Öğrt & 19 & 224,68 & & & & \\
\hline & (10) Özel Ĕ̆t Öğrt & 34 & 109,31 & & & & \\
\hline & (11) Diğer & 48 & 256,46 & & & & \\
\hline
\end{tabular}


Tablo 6 incelendiğinde, öğretmenlerin özel gereksinimli bireylere yönelik tutum puanları arasında gözlenen farkın hangi gruplardan kaynaklandığını belirlemek amacıyla KruskalWallis $\mathrm{H}$ testinden yararlanılmıştır. Öğretmenlerin branş değişkenine göre özel gereksinimli bireylere yönelik tutumlarında duyarlılık faktöründe anlamlı bir farklılık olmamasına karşın beğeni, olumsuz tutum faktöründe ve ölçeğin tamamında anlamlı bir farklılık bulunmuştur.

Mann-Whitney U testi ile yapılan çoklu karşılaştırmalar sonucunda beğeni alt boyutundaki anlamlı farkın, özel eğitim öğretmenleri lehine Türkçe öğretmenleri, sınıf öğretmenleri, sosyal bilgiler öğretmenleri, İngilizce öğretmenleri, din kültürü öğretmenleri, matematik öğretmenleri ve diğer branşlardaki öğretmenler arasında olduğu tespit edilmiştir. Yine beğeni alt boyutundaki anlamlı farkın rehber öğretmenler lehine Türkçe öğretmenleri, sınıf öğretmenleri, İngilizce öğretmenleri, din kültürü öğretmenleri, matematik öğretmenleri ve diğer branşlardaki öğretmenler arasında olduğu tespit edilmiştir. Bu bulguya göre özel eğitim öğretmenleri ve rehber öğretmenlerin meslektaşlarına göre özel gereksinimli bireylerin eğitimine anlamlı düzeyde ilgi duydukları ve yaptıkları işten daha fazla zevk aldıkları söylenebilir.

Tablo 6 incelendiğinde özel gereksinimli öğrencilere yönelik duyarlılığ öğretmenlerin, rehber öğretmenler ve özel eğitim öğretmenler olduğu en düşük duyarlılığa sahip olan öğretmenlerin sosyal bilgiler öğretmenleri olduğu tespit edilmiştir. Duyarlılık alt boyutunda anlamlı farkın ise rehber öğretmenler lehine sosyal bilgiler öğretmenleri ve diğer branşlardaki öğretmenler arasında olduğu tespit edilmiştir. Olumsuz tutum alt boyutu incelendiğinde özel gereksinimli bireylere yönelik en az olumsuz tutuma sahip olan öğretmenlerin, özel eğitim öğretmenleri ve rehber öğretmenler olduğu, en fazla olumsuz tutuma sahip olan öğretmenlerin ise matematik öğretmenleri olduğu tespit edilmiştir. Olumsuz tutum alt boyutunda anlamlı farkın ise, özel eğitim öğretmenleri lehine Türkçe öğretmenleri, sosyal bilgiler öğretmenleri, sınıf öğretmenleri, İngilizce öğretmenleri, fen bilgisi öğretmenleri, din kültürü öğretmenleri, matematik öğretmenleri, rehber öğretmenler, okul öncesi öğretmenleri ve diğer branşlardaki öğretmenler arasında olduğu tespit edilmiştir. Yine olumsuz tutum alt boyutundaki anlamlı farkın rehber öğretmenler lehine Türkçe öğretmenleri, sosyal bilgiler öğretmenleri, sınıf öğretmenleri, İngilizce öğretmenleri, din kültürü öğretmenleri, matematik öğretmenleri ve diğer branşlardaki öğretmenler arasında olduğu tespit edilmiştir.

Öğretmenlerin çevrelerinde veya ailelerinde özel gereksinimli bireyle karşılaşma değişkenine göre özel gereksinimli bireylere yönelik tutum puanları arasında anlamlı bir farklılık olup olmadığına ilişkin bulgular tablo 7'de sunulmuştur.

Tablo 7. Öğretmenlerin çevrelerinde veya ailelerinde özel gereksinimli bireyle karşılaşma durumu değişkenine göre özel gereksinimli bireylere yönelik tutumlarını Yansıtan Bulgular

\begin{tabular}{llccccc}
\hline Faktörler & $\begin{array}{l}\text { Yakını Olup } \\
\text { Olmama }\end{array}$ & $\mathbf{N}$ & $\begin{array}{c}\text { Sıra farkları } \\
\text { ort. }\end{array}$ & $\begin{array}{c}\text { Sira } \\
\text { toplamı }\end{array}$ & U & p \\
\hline \multirow{2}{*}{ Beğeni } & Evet & 149 & 251.14 & 37419.5 & 21286.5 & .068 \\
& Hayır & 319 & 226.73 & 73326.5 & & \\
\hline
\end{tabular}




\begin{tabular}{lllllll}
\hline \multirow{2}{*}{ Duyarlılık } & Evet & 149 & 252.75 & 37660.0 & 21046.0 & $.035^{*}$ \\
& Hayır & 319 & 225.97 & 72086.0 & & \\
\hline \multirow{2}{*}{ Olumsuz Tutum } & Evet & 149 & 233.78 & 34832.5 & \multirow{2}{*}{23657.5} & .936 \\
& Hayır & 319 & 234.84 & 74913.5 & & \\
\hline
\end{tabular}

"p<0,05

Tablo 7 incelendiğinde, öğretmenlerin özel gereksinimli bireylere yönelik tutum puanları arasında gözlenen farkın hangi gruplardan kaynaklandığını belirlemek amacıyla MannWhitney U testinden yararlanılmıştır. Öğretmenlerin çevrelerinde veya ailelerinde özel gereksinimli birey bulunma değişkenine göre özel gereksinimli bireylere yönelik tutumlarında ölçeğin beğeni ve olumsuz tutum faktöründe istatistiksel olarak anlamlı bir farklılık oluşmadığı görülmüştür. Öğretmenlerin çevrelerinde veya ailelerinde özel gereksinimli birey bulunma değişkenine göre duyarlılık faktöründe anlamlı bir farklılık bulunmuştur. Buna göre çevrelerinde ya da ailesinde özel gereksinimli birey bulunmayan öğretmenlerin bulunan öğretmenlere göre duyarlılıklarının daha yüksek olduğu tespit edilmiştir.

\section{Tartışma, Sonuç ve Öneriler}

Araştırma sonucunda öğretmenlerin özel gereksinimli bireylere yönelik tutumlarında cinsiyet değişkenine göre anlamlı farklılık bulunmamıştır. Kadın ve erkek öğretmenlerin özel gereksinimli bireylere yönelik tutumlarının benzer düzeyde olduğu söylenebilir. Literatür incelendiğinde elde edilen sonuca benzer sonuçlar elde edildiği görülmektedir. Çolak ve Çetin (2014) ve Parasuram (2006) yaptığı çalışmada öğretmenlerin özel gereksinimli bireylere yönelik tutumlarında cinsiyet değişkenine göre anlamlı bir fark olmadığı sonucuna ulaşılmıştır. Akyıldız (2017), Demir Atalay ve Atalay (2017) tarafından yapılan çalışmalarda öğretmen adaylarının; Yıldırım Sarı, Bektaş ve Altıparmak (2010) hemşirelik öğrencilerinin cinsiyete göre özel gereksinimli bireylere yönelik tutumlarında anlamlı fark olmadığ sonucuna ulaşılmıştır. Yaralı (2015) tarafından yapılan çalışmada ise beğeni ve olumsuz tutum alt boyutlarında cinsiyet değişkenine göre anlamlı bir farklılık tespit edilmezken duyarlılık boyutunda kadın öğretmen adayları lehine anlamlı bir farklılık belirlenmiştir. McQuilkin, Freitag ve Harris (1990) üniversite ve Cowardin (1986) lise öğrencileri ile yapmış olduğu çalışmada kız öğrencilerin erkeklere göre daha olumlu tutumlara sahip olduğunu belirlemiştir. Karademir, Açak, Türkçapar ve Eroğlu (2018) beden eğitimi öğretmen adayları ile yaptıkları çalışmada kadınların zihinsel engelli bireylere yönelik tutumlarının erkeklere göre daha yüksek düzeyde olduğunu belirlemiştir.

Araştırmaya katılan öğretmenlerin özel gereksinimli bireylere yönelik tutumlarının kıdem değişkenine göre duyarlılık faktöründe, olumsuz tutum faktöründe ve ölçeğin tamamında anlamlı bir farklılık tespit edilmiştir. Ortaya çıkan farkın duyarlılık faktöründe 0-5 yıl, 6-10 yıl ve 16 yıl ve üstü kıdeme sahip öğretmenler arasında 0-5 yıl kıdeme sahip öğretmenlerin lehine, olumsuz tutum faktöründe 0-5 yıl kıdeme sahip öğretmenler ile 6-10 yıl ve 11-15 yıl görev yapan öğretmenler arasında 0-5 yıl görev yapan öğretmenlerin lehine anlamlı çıkması öğretmenlerin hizmet süresi arttığında özel gereksinimli bireylere yönelik olumsuz tutumlarının arttı̆̆ı söylenilebilir. Benzer bir şekilde Güleryüz ve Özdemir (2015), Parasuram (2006), Toy ve Duru (2016) yapmış oldukları araştırmada hizmet süresi az olanların özel 
gereksinimli bireylere yönelik tutumlarının daha yüksek olduğu sonucuna ulaşmışlardır. Bu durum araştırma sonuçlarıyla örtüşmektedir.

Araştırmaya katılan öğretmenlerin öğretim kademelerine göre özel gereksinimli bireylere yönelik tutumlarında anlamlı bir farklılık bulunmamıştır. Her öğretim kademesinde özel gereksinimli bireylerle çalışabilme ihtimalinin bulunması, öğretmenlerin üniversite eğitimleri boyunca özel eğitim alanına yönelik derslerin okutulması özel gereksinimli bireylere yönelik tutumlarının benzer olmasının sebebi olabilir. Köse (2018) yapmış olduğu araştırmada ilkokul öğretmenlerinin kaynaştırma öğrencilerine yönelik tutumlarının daha olumlu olduğu sonucunu elde etmiştir. Bunun sebebi ilkokul öğretmenlerinin öğrenme sürecinin tamamını aynı öğrencilerle geçirmesi ve kaynaştırma öğrencilerini tanıma fırsatını daha fazla yakalamaları olabilir.

Öğretmenlerin branş değişkenine göre özel gereksinimli bireylere yönelik tutumlarında beğeni ve olumsuz faktöründe rehber öğretmenler ve özel eğitim öğretmenleri lehine anlamlı fark ortaya çıkmıştır. Duyarlılık faktöründe ise rehber öğretmenler lehine anlamlı fark ortaya çıkmıştır. Öğretmenlerin özel gereksinimli bireyler hakkında eğitim almış olmasının olumlu tutum ve becerilerin geliştirilmesinde önemli olduğu düşünülmektedir. (Bender, Vail, Scott, 1995; Sharma, Forlin, Loreman, Earle, 2006; Hollins, 2011). Yapılan bu çalışmada özel eğitim öğretmenlerinin özel gereksinimli bireylere yönelik en olumlu tutuma sahip olmaları alan yazındaki çalışmalar ile örtüşmektedir. Nitekim yapılan çalışmalar özel gereksinimli bireyler hakkında verilen eğitimin olumlu tutum geliştirmede etkili olduğunu da ortaya koymuştur (Akçamete ve Kargın, 1994; Orel, Zerey ve Töret 2004; Gözün ve Yıkmış, 2004; Forlin, Loreman, Sharma ve Earle, 2009; Tavil ve Özyürek, 2009; Costello ve Boyle, 2013; Alptekin ve Batık, 2013; Şahin ve Güldenoğlu, 2013). Çitil, Karakoç, Küçüközyiğit (2018) ise yaptıkları çalışmada öğretmen adaylarının özel eğitim ve engelliler hakkında bilgi düzeyleri artmış olmasına karşın engelli bireylere yönelik tutumlarında anlamlı bir değişikliğin gerçekleşmediğini tespit etmiştir.

Araştırma sonucunda öğretmenlerin çevrelerinde veya ailelerinde özel gereksinimli birey bulunma değişkenine göre özel gereksinimli bireylere yönelik tutumlarında duyarlılık faktöründe anlamlı bir farklılık bulunmuştur. Buna göre çevrelerinde ya da ailesinde özel gereksinimli birey bulunmayan öğretmenlerin bulunan öğretmenlere göre tutumlarının daha yüksek olduğu görülmektedir. Benzer bir şekilde Çolak ve Çetin (2014) yaptığı çalışmada ailelerinde engelli birey bulunan öğretmenlerin bulunmayanlara göre engelli bireylere yönelik anlamlı düzeyde olumlu bir tutuma sahip oldukları tespit edilmiştir. Parasuram (2006) yaptığ çalışmada ise ailelerinde engelli bir birey olan öğretmenler ile olmayan öğretmelerin tutumları arasında anlamlı bir farklılık olmadığını tespit etmiştir. Nitekim alan yazında öğretmenlerin sinıflarında yer alan özel gereksinimli öğrencilerin yetersizlik düzeyi ile tutumları arasında negatif yönlü ilişkili olduğunu gösteren araştırmalar da bulunmaktadır (Ellins ve Porter, 2005; Forlin ve Chambers, 2011). Aksoy ve Yıldırım (2008) tarafından yapılan bir çalışmada ise engelli kardeşe sahip çocukların kardeş ilişkileri ve kardeşlerini kabullenme düzeyinde negatif bir ilişki olduğu görülmüştür. Bu durumda özel gereksinimli bireylerle yaşamanın zorluklarının tutumda etkili olduğu söylenebilir.

Eğitim yaşantısı içerisinde ailelerinden sonra çocuklarla en fazla zaman geçiren öğretmenlerin özel gereksinimli bireylere yönelik tutumlarının incelendiği bu çalışmada; kadın öğretmenlerin tutum puanları daha yüksek olsa da erkek öğretmenlerin tutumlarından farklılaşmadığı; duyarlılığı yüksek olan öğretmenlerin genç öğretmenler olduğu; rehber 
öğretmenler ve özel eğitim öğretmenlerinin diğer branşlardaki öğretmenlerden daha olumlu bir tutuma sahip oldukları ve ailesinde özel gereksinimli birey olan öğretmenlerin diğer öğretmenlere göre daha duyarlı oldukları belirlenmiştir.

Araştırmada kıdemi düşük öğretmenlerin özel gereksinimli bireylere yönelik duyarlılıklarının yüksek olmasının yanında olumsuz tutumlarının da yüksek olması özel gereksinimli öğrencilere daha iyi nasıl yaklaşacakları ile ilgili yeterli bilgi ve tecrübeye sahip olmamalarından kaynaklanıyor olabilir. Bunun yanında kıdemi fazla olan öğretmenlerin ise olumsuz tutumları düşük olduğu halde duyarlılığın da düşük olması mesleki tükenmişliğin bir göstergesi olarak kabul edilebilir.

Nihayetinde öğretmenlerin okullardaki varlık sebebi öğrenciler ise özel gereksinimli olsun ya da olmasın öğrencilere yönelik tutumlarının olumlu olması temenni edilen bir durumdur. Farklılıklara saygı ve tahammül düzeyi kişinin sahip olduğu kültürel değer ve insana bakış açısından da etkilense de aldığı eğitimin kalitesi belirleyici konumdadır. İnsan bilmediği şeye karşı mesafeli ve kaygılı yaklaştığından yapılması gereken; lisans eğitimi esnasında öğretmen adaylarına, sonrasında ise öğretmenlere branş farkı gözetilmeksizin özel eğitim konusunda yeterli eğitimin verilmesidir.

\section{Kaynakça}

Akçamete, G. ve Kargın, T. (1994). Hizmet içi eğitim programının öğretmenlerin işitme engelli çocuklara yönelik tutumlarına etkisi. Özel Eğitim Dergisi, 1(4), 13-19.

Akman, B. ve Okyay, Ö. (2004). Sınıfında Engelli Çocuk Bulunan ve Bulunmayan Okul Öncesi Öğretmenlerinin Engelli Çocukların Kaynaştırılmasına İlişkin Görüşlerinin Karşılaştırılması. XVIII. Ulusal Eğitim Bilimleri Kurultayı. 1-3 Ekim. İzmir.

Aksoy, A. B., \& Yıldırım, G. B. (2008). Farklı engel grubundan engelli kardeşe sahip çocukların kardeş ilişkileri ile kardeşlerini kabullenmeleri arasındaki ilişkinin incelenmesi. Kuram ve Uygulamada Eğitim Bilimleri Dergisi, 8(3), 751-779.

Akyıldız, S. (2017). Öğretmen adaylarının engelli bireylere yönelik tutumlarının incelenmesi. Sosyal Politika Çalışmaları Dergisi, 17(39), 141-169. DOI: 10.21560/spcd.vi.338158

Alexander, C., \& Strain, P. S. (1978). A review of educators' attitudes toward handicapped children and the concept of mainstreaming. Psychology in the Schools, 15(3), 390-396. DOI: 10.1002/15206807(197807)15:3<390::AID-PITS2310150316>3.0.CO;2-S

Alptekin, S. ve Batık, V.M. (2013). Özel eğitim bölümü öğrencilerinin yetersizlikten etkilenmiş kişilere yönelik tutumlarına özel eğitim dersinin etkisi. International Journal of Educational $\begin{array}{llll}\text { Research, } & \text { 4(4), 18-34. Retrieved from }\end{array}$ http://dergipark.ulakbim.gov.tr/ijer/article/view/1073000318

Altun, T. ve Gülben, A. (2009). Okul öncesinde özel gereksinim duyan çocukların eğitimindeki uygulamalar ve karşılaşılan sorunların öğretmen görüşleri açısından değerlendirilmesi. Selçuk Üniversitesi Ahmet Keleşoğlu Eğitim Fakültesi Dergisi, 28, 253 -272.

Ardıç, A. (2012). Özel gereksinimli bireylere yönelik tutumlar. Veysel Aksoy (Ed.), Özel Eğitim içinde (s.237-266). Pegem Akademi Ankara. 
Atalay, T. D., \& Atalay, Ö. (2017). Edebiyat öğretmen adaylarının özel gereksinimli bireylere yönelik tutumları ve bazı değişkenlerle ilişkisi. e-Kafkas Eğitim Araştırmaları Dergisi, 4(3), 20-29. DOI: 10.30900/kafkasegt.335214

Atay, M. (1995). Özel gereksinimli çocukların normal yaşıtları ile birlikte eğitim aldıkları kaynaştırma programlarına karşı öğretmen tutumları üzerine bir inceleme. (Yayınlanmamış doktora tezi). Hacettepe Üniversitesi, Ankara.

Atıcı, R. (2014). Sınıf içerisinde öğrenci davranışlarına etki eden etmenler. The Journal of Academic Social Science Studies, 28(2), 413-427. DOI: 10.9761/JASSS2445

Avramidis, E., Bayliss, P. \& Burden, R. (2000). Student teachers' attitudes towards the inclusion of children with special educational needs in the ordinary school. Teaching And Teacher Education, 16, 277-293. DOI: 10.1016/S0742-051X(99)00062-1

Aydın, A., \& Tekneci, E. (2013). Zihin engelliler öğretmenliği öğrencilerinin öğretmenlik mesleğine yönelik tutumları ile kaygı düzeyleri. Pegem Eğitim ve Öğretim Dergisi, 3(2), 01-12.

Bandura, A. (1986). The explanatory and predictive scope of self-efficacy theory. Journal of social and clinical psychology, 4(3), 359-373. DOI: 10.1521/jscp.1986.4.3.359

Batu, S., Kırcaali-İftar, G. \& Uzuner, Y. (2004). Özel gereksinimli öğrencilerin kaynaştırıldığı bir kız meslek lisesindeki öğretmenlerin kaynaştırmaya ilişkin görüş ve önerileri. Ankara Üniversitesi Eğitim Bilimleri Fakültesi Özel Eğitim Dergisi, 5 (2), 33-50. DOI: 10.1501/Ozlegt_0000000082

Bender, W. N., Vail, C. O., \& Scott, K. (1995). Teachers attitudes toward increased mainstreaming: implementing effective instruction for students with learning disabilities. Journal of Learning Disabilities, 28(2), 87-94. DOI: 10.1177/002221949502800203

Bilen, E. (2007). Sınıf Ö̆̆retmenlerinin Kaynaştırma Uygulamalarında Karşılaştıkları Sorunlara İlişkin Görüşleri ve Çözüm Önerileri. (Yayımlanmamış Yüksek Lisans Tezi). Dokuz Eylül Üniversitesi/Eğitim Bilimleri Enstitüsü, İzmir.

Bizer GY, Barden JC, Petty RE. (2003). Attitudes. Encyclopedia of Cognitive Science. London: Nature Publishing Group, 247-53.

Brownlee, J., \& Carrington, S. (2000), Opportunities for authentic experience and reflection: A teaching programme design to change attitudes towards disability for pre-service teachers, Support for Learning, 15 (3), 99-105. DOI: 10.1111/1467-9604.00157

Cagney, T. L. (2009). Attitudes of general education teachers toward including students with special needs. (Graduate Theses and Dissertations). Iowa State University. Retrieved from https:/lib.dr.iastate.edu/etd/10817.

Costello, S., \& Boyle, C. (2013). Pre-service secondary teachers' attitudes towards inclusive education. Australian Journal of Teacher Education, 38(4), 128-143. DOI: 10.14221/ajte.2013v38n4.8

Cowardin, N. W. (1986). Adolescent characteristics associated with acceptance of handicapped peers. Adolescence, 21(84), 931.

Cüceloğlu, D. (1996) İnsan ve Davranışı Psikolojinin Temel Kavramları. (6. baskı). İstanbul: Remzi Kitapevi.

Çapa Y., \& Çil, N. (2000). Öğretmen adaylarının öğretmenlik mesleğine yönelik tutumlarının farklı değişkenler açısından incelenmesi. Hacettepe Üniversitesi Ĕ̆itim Fakültesi Dergisi, 18, 69-73. 
Çelik, S. (2011). Öğretmen Tutumları ile İlköğretim 5. Sinıf Öğrencilerinin Benlik Saygısı Düzeyleri Arasındaki İlişki. (Yayımlanmamış Yüksek Lisans Tezi). Selçuk Üniversitesi/Sosyal Bilimler Enstitüsü, Konya.

Çitil, M., Karakoç, T. \& Küçüközyiğit, M. S. (2018). Özel eğitim lisans dersinin öğretmen adaylarının bilgi düzeylerine ve engellilere yönelik tutumlarına etkisi. Abant İzet Baysal Üniversitesi Ĕ̆itim Fakültesi Dergisi, 18 (2), 815-833. DOI: 10.17240/aibuefd.2018..-431449

Çolak, M., \& Çetin, C. (2014). Öğretmenlerin Engelliliğe Yönelik Tutumları Üzerine Bir Araştırma. Dokuz Eylül Üniversitesi İktisadi ve İdari Bilimler Fakültesi Dergisi, 29(1), 191-211. Retrieved from https://dergipark.org.tr/en/pub/deuiibfd/issue/22719/242482

Çuhadar, Y. (2006). İlköğretim okulu 1-5. Sinuflarda kaynaştırma eğitimine tabi olan çocuklar için bireyselleştirilmiş eğitim programı hazırlanması, uygulanması, izlenmesi ve değerlendirilmesi ile ilgili olarak sinı öğretmenlerinin ve yöneticilerin görüşlerinin belirlenmesi. (Yayımlanmamış Yüksek Lisans Tezi). Zonguldak Karaelmas Üniversitesi/Sosyal Bilimler Enstitüsü, Zonguldak.

Dalğar, G. (2011). Okulöncesi öğretmenlerinin ve okulöncesi öğretmen adaylarının kaynaştırmaya ilişkin görüşlerinin karşılaştırılması. (Yayımlanmamış Yüksek Lisans Tezi). Mehmet Akif Ersoy Üniversitesi/Sosyal Bilimler Enstitüsü, Burdur.

Daşbaş, S., Kesen, N. F., \& Eryılmaz, C. (2013). Eğitim kurumlarında görev yapan öğretmenlerin engellilere yönelik tutumları. Sağ lık ve Toplum, 23, 35-49.

Demir Atalay, T, Atalay, Ö. (2017). Edebiyat öğretmen adaylarının özel gereksinimli bireylere yönelik tutumları ve bazı değişkenlerle ilişkisi. e-Kafkas Ĕ̆itim Araştırmaları Dergisi, 4 (3) , 20-29 . DOI: 10.30900/kafkasegt.335214

Demirezen, S., \& Akhan, N. E. (2016). Sosyal bilgiler öğretmenlerinin kaynaştırma uygulamalarına ilişkin görüşleri. Abant İzzet Baysal Üniversitesi Eğitim Fakültesi Dergisi, 16(2), 1206-1223.

Ellins, J., \& Porter, J. (2005). Departmental differences in attitudes to special educational needs in the secondary school. British Journal of Special Education, 32(4), 188-195. DOI: 10.1111/j.14678578.2005.00396.x

Enç, M., Özsoy, Y., \& Çağlar, D. (1987). Özel eğitime giriş. Ankara Üniversitesi Basımevi.

Engin, A. O., Tösten, R., Kaya, M. D., \& Köselioğlu, Y. S. (2014). İlköğretim öğretmenlerinin kaynaştırma uygulamasıyla ilgili tutum ve görüşlerinin değerlendirilmesi (Kars İli Örneği). Kafkas Üniversitesi Sosyal Bilimler Enstitüsü Dergisi, (13), 27-44. DOI:10.9775/kausbed.2014.003

Eripek, S. (2007). Özel Eğitim ve Kaynaştırma Uygulamaları. S. Eripek (Ed.) İlköğretimde Kaynaştırma (s.1-21). Eskişehir: Anadolu Üniversitesi.

Erişkin, A. Y., Kıraç, S. Y., \& Ertuğrul, Y. (2012). Sınıf öğretmenlerinin kaynaştırma uygulamalarına ilişkin görüşlerinin değerlendirilmesi. Milli Ĕ̆gitim Dergisi, (193), 200-213. Retrieved from https://dergipark.org.tr/en/pub/milliegitim/issue/36181/406769

Fakolade, O. A., Adeniyi, S. O., \& Tella, A. (2009). Attitude of teachers towards the inclusion of special needs children in general education classroom: the case of teachers in some selected schools in Nigeria. International Electronic Journal of elementary education, 1(3), 155-169.

Ferguson, D.L.; Ralph, G.R. (1996). The changing role of special educators: A development waiting for a change. Contemporary Education, 68(1), 49-51. 
Fırat, T. (2014). Farklı eğitim kademelerinde görev yapacak öğretmen adaylarının kaynaştırmaya yönelik tutumlarının incelenmesi. Adryaman Üniversitesi Sosyal Bilimler Enstitüsü Dergisi, 18, 597-628. DOI: $10.14520 /$ adyusbd.808

Forlin, C., \& Chambers, D. (2011). Teacher preparation for inclusive education: increasing knowledge but raising concerns. Asia-Pacific Journal of Teacher Education, 39(1), 17-32. DOI: 10.1080/1359866X.2010.540850

Forlin, C., Loreman, T., Sharma, U., \& Earle, C. (2009). Demographic differences in changing preservice teachers' attitudes, sentiments and concerns about inclusive education. International Journal of Inclusive Education, 13(2), 195-209. DOI: 10.1080/13603110701365356

Garner, P. (1996). Students' views on special educational needs courses in initial teacher education. British Journal of Special Education, 23(4), 176-79. DOI: 10.1111/j.1467-8578.1996.tb00972.x

Genç, Y. (2016a). Gençleri fiziksel şiddete iten sebepler, öğrenme yolları ve şiddet eğilimleri. The Journal of Academic Social Science Studies,44, 51-62. DOI: 10.9761/JASSS3321

Genç, Y. (2016b). Gençlerin sözel şiddeti öğrenme yoları ve şiddet eğilimleri. The Journal of Academic Social Science, (30), 144-155. DOI: 10.16992/ASOS.1335

Gözün, Ö., \& Yıkmış, A. (2004). Öğretmen adaylarının kaynaştırma konusunda bilgilendirilmelerinin kaynaştırmaya yönelik tutumlarının değişimindeki etkililiği. Ankara Üniversitesi Eğitim Bilimleri Fakültesi Özel Ĕ̆itim Dergisi, 5 (2), 65-77. Retrieved from https://dergipark.org.tr/en/download/article-file/159204

Güleryüz, B. (2014). Sinı öğretmenlerinin ve sını öğretmeni adaylarının kaynaştırma eğitimine ilişkin görüşlerinin belirlenmesi. (Yayınlanmamış Yüksek Lisans Tezi). Bülent Ecevit Üniversitesi/Sosyal Bilimler Enstitüsü, Zonguldak.

Güleryüz, B., \& Özdemir, M. (2015). Sınıf öğretmenlerinin ve sınıf öğretmeni adaylarının kaynaştırma eğitimine ilişkin tutumlarının incelenmesi. Uşak Üniversitesi Sosyal Bilimler Dergisi, 8(3), 53-64. Retrieved from https://dergipark.org.tr/en/pub/usaksosbil/issue/21660/232934

Hollins, E. R. (2011). Teacher preparation for quality teaching. Journal of Teacher Education, 62(4), 395-407. DOI: $10.1177 / 0022487111409415$

İnceoğlu, M. (2010). Tutum, algı, iletişim. İstanbul. Beykent Üniversitesi Yayınları.

Karademir, T., Açak. M., Türkçapar, Ü., \& Eroğlu, H. (2018). Beden eğitimi öğretmen adaylarının zihinsel engellilere yönelik tutumlarının belirlenmesi. Beden Eğitimi ve Spor Bilimleri Dergisi, 20(3), 103-112. Retrieved from https://dergipark.org.tr/en/pub/ataunibesyo/issue/39710/452114

Karasar, N. (1999). Bilimsel Araştırma Yöntemleri. Ankara: Nobel Yayın Dağıtım.

Kargın, T., Güldenoğlu, B., \& Şahin, F. (2010). Genel eğitim sınıflarındaki özel gereksinimli öğrenciler için yapılması gereken uyarlamalara ilişkin sınıf öğretmenlerinin görüşlerinin incelenmesi, Kuram ve Uygulamada Ĕ̆itim Bilimleri, 10(4), 2431-2464.

Kayhan, N., Şengül, A., \& Akmeşe, P. P. (2012). İlköğretim birinci ve ikinci kademe öğretmen adaylarının kaynaştırmaya ilişkin görüşlerinin incelenmesi. Ĕ̆itim ve Öğretim Araştırmalar Dergisi, 1(3), 268-278. Retrieved from http://www.jret.org/FileUpload/ks281142/File/28z.kayhan.pdf 
Kocabaşoğlu, H. (2016). Meslek lisesi çocuk gelişimi ve eğitimi bölümü son sinfföğrencilerinin özel eğitim dersine yönelik tutumlarının belirlenmesi. (Yayımlanmamış yüksek lisans tezi). Yakındoğu Üniversitesi/Eğitim Bilimleri Enstitüsü, Lefkoşa.

Köse, A. (2018). Sinıf ve branş öğretmenlerinin kaynaştırma öğrencilerine yönelik tutumlarının incelenmesi. (Yayımlanmamış yüksek lisans tezi). Fırat Üniversitesi/ Eğitim Bilimleri Enstitüsü, Elazı̆g.

Kösterelioğlu, İ. (2013). Engelli bireylerin eğitilmesine yönelik tutum ölçeğinin geliştirilmesi. Ahi Evran Üniversitesi Kırşehir Eğitim Fakültesi Dergisi, 14(3), 211-226. Retrieved from https://dergipark.org.tr/en/pub/kefad/issue/59470/854580

Kuzu S. (2011). Öğretmen adaylarımın kaynaştırma eğitimine yönelik tutumları ve öz duyarlllı düzeylerinin karşılaştırılması. (Yayımlanmamış yüksek lisans Tezi). Marmara Üniversitesi/Eğitim Bilimleri Enstitüsü, İstanbul.

McQuilkin, J. I., Freitag, C. B., \& Harris, J. L. (1990). Attitudes of college students toward handicapped persons. Journal of College Student Development, 31(1), 17-22.

Orel, A., Zerey, Z., \& Töret, G. (2004). Sınıf öğretmeni adaylarının kaynaştırmaya yönelik tutumlarının incelenmesi. Ankara Üniversitesi Eğitim Bilimleri Fakültesi Özel Eğitim Dergisi, 5(1), 23-33. Retrieved from https://dergipark.org.tr/en/download/article-file/159208

Özbaba, N. (2000). Okul öncesi eğitimcilerin ve ailelerin özel eğitime muhtaç çocuklar ile normal çocukların entegrasyonuna (kaynaştırılmasına) karşı tutumları. (Yayımlanmamış yüksek lisans tezi). Marmara Üniversitesi/Eğitim Bilimleri Enstitüsü, İstanbul

Özyürek, M. (2006). Engellilere Yönelik Tutumların Değiştirilmesi. Ankara: Kök Yayıncılık.

Özyürek, M. (2013). Engellilere Yönelik Tutumların Değiştirilmesi (4. Baskı). Ankara: Kök Yayıncilik.

Parasuram, K. (2006). Variables that affect teachers' attitudes towards disability and inclusive education in Mumbai, India. Disability \& Society, 21(3), 231-242. DOI: 10.1080/09687590600617352

Petty, E. R. ve Caciopp, T. J. (1996) Attitudes and Persuasion: Classic and Contemporary Approaches. Ohio State Univesity, Westview Press, Oxford.

Rizzo, T. L. (1985). Attributes related to teachers' attitudes. Perceptual And Motor Skills, 60(3), 739742. DOI: $10.2466 / \mathrm{pms} .1985 .60 .3 .739$

Saidoğlu, Ö. (2011). Sını öğretmenlerinin kaynaştırmaya ilişkin sorunları, beklentileri ve önerilerine yönelik nitel bir araştırma. (Yayımlanmamış doktora tezi). Uludağ Üniversitesi/Eğitim Bilimleri Enstitüsü, Bursa.

Sarı, H., \& Bozgeyikli, H. (2003). Öğretmen adaylarının özel eğitime yönelik tutumlarının incelenmesi: karşılaştırmalı bir araştırma. Selçuk Üniversitesi Sosyal Bilimler Enstitüsü Dergisi, 9, 183-203. Retrieved from http://dergisosyalbil.selcuk.edu.tr/susbed/article/view/789/741

Sarı, H., \& Saygın, F. (2002). Üniversite Öğrencilerinin Özel Eğitim Dersi Almalarına Yönelik İhtiyaçlarının Analizi, XI. Ulusal Özel Eğitim Kongresi Bildirileri 11-13 Kasım, 2001, Konya: Eğitim Kitabevi, 61-79

Sarı, H., Çeliköz, N., \& Seçer, Z (2009). An analysis of pre-school teachers' and student teachers' attitudes to inclusion and their self-efficacy. International Journal of Special Education, 24, 30-44. Retrieved from https://eric.ed.gov/?id=E]877918 
Sharma, U., Forlin, C., Loreman, T., \& Earle, C. (2006). Pre-service teachers' attitudes, concerns and sentiments about inclusive education: an international comparison of novice pre-service teachers. International Journal of Special Education, 21(2), 80-93. Retrieved from https://eric.ed.gov/?id=EJ843609

Siegel, J. (1992), Teachers' Attitude Toward Their Integrated Learning Handicapped Students: Relationship to Teacher Perceptions of Students' Behaviour. (92), 17. Retrieved from https://files.eric.ed.gov/fulltext/ED359718.pdf

Şahin, F., \& Güldenoğlu, B. (2013). Engelliler konusunda verilen eğitim programının engellilere yönelik tutumlar üzerindeki etkisi. Amasya Üniversitesi Ĕ̆itim Fakültesi Dergisi, 2(1), 214-239. Retrieved from https://dergipark.org.tr/en/pub/amauefd/issue/1728/21182

Tavil, Y. Z. ve Özyürek, M. (2009). Gerçekçi bilgilendirme ve etkileşimde bulunmanın özel eğitim öğretmen adaylarının engelli kişilere yönelik tutumlarının değişmesine etkisi. EKEV Akademi Dergisi, 13(39), 265-276.

Tavşancıl, E. (2014). Tutumların Ölçülmesi ve SPSS ile Veri Analizi (5). Ankara: Nobel Yayıncılık.

Temel, Z. F. (2000). Okul öncesi eğitimcilerinin engellilerin kaynaştırılmasına ilişkin görüşleri. Hacettepe Üniversitesi Eğitim Fakültesi Dergisi, 18(18). Retrieved from https://dergipark.org.tr/en/download/article-file/88015

Temizkan, M. (2008). Türkçe öğretmeni adaylarının öğretmenlik mesleğine önelik tutumları üzerine bir araştırma. Türk Ĕ̆itim Bilimleri Dergisi, 6(3), 461-486.

Toy, S. N. ve Duru, S. (2016). Sınıf öğretmenlerinin öğretmen öz yeterlikleri ile kaynaştırma eğitimine ilişkin yeterlik inançlarının karşılaştırılması. Ege Eğitim Dergisi, 17(1), 146-173. DOI: 10.12984/eed.00332

Vaz S, Wilson N, Falkmer M, Sim A, Scott M, Cordier R, et al. (2015) Factors associated with primary school teachers' attitudes towards the inclusion of students with disabilities. PLoS ONE 10(8): e0137002. DOI: 10.1371/journal.pone.0137002

Yaralı, D. (2015). Özel gereksinimli bireylere yönelik bir tutum ölçeğinin geliştirilmesi. e-Kafkas Eğitim Araştırmaları Dergisi, 2(3). Retrieved from https://dergipark.org.tr/en/download/articlefile/180101

Yavuz, C. (2005). Okul öncesi eğitimde kaynaştırma eğitimi uygulamalarının değerlendirilmesi. (Yayımlanmamış Yüksek Lisans Tezi). Gazi Üniversitesi/Eğitim Bilimleri Enstitüsü Çocuk Gelişimi ve Eğitimi Anabilim Dalı, Ankara.

Yıldırım Sarı, H., Bektaş, M. ve Altıparmak, S. (2010). Hemşirelik öğrencilerinin engellilere yönelik tutumlarının belirlenmesi. Yeni Tip Dergisi, 27: 80-83.

Yiğiter, S. (2005). Sinıf öğretmenlerinin özel öğrenme güçlüğüne ilişkin bilgi düzeyleri ile özel öğrenme güçlüğ̈̈ olan çocuklarm kaynaştırılmasına yönelik tutumlar arasındaki ilişkinin incelenmesi. (Yayımlanmamış Yüksek Lisans Tezi). Marmara Üniversitesi/Eğitim Bilimleri Enstitüsü, İstanbul 